Note

\section{Genetic Transformation of Bacillus brevis with Plasmid DNA by Electroporation}

\author{
Hiroaki TaKagi, Shogo KagiYama, \\ Kiyoshi Kadowaki, Norihiro Tsukagoshi* \\ and Shigezo UDAKA* \\ Research Laboratory, Higeta Shoyu Co., Ltd., \\ Choshi, Chiba 288, Japan \\ * Department of Food Science and Technology. \\ Faculty of Agriculture, Nagoya University, \\ Chikusa-ku, Nagoya 464, Japan
}

Received June 22, 1989

Bacillus brevis HPD31 ${ }^{1)}$ has been shown to be an excellent host bacterium for the extracellular production of foreign proteins such as thermophilic $\alpha$-amylase from Bacillus stearothermophilus, ${ }^{2\}}$ swine pepsinogen ${ }^{3)}$ and human epidermal growth factor, ${ }^{4)}$ because of its high protein-productivity and that it has no detectable extracellular protease activity. ${ }^{1)}$

The Tris-PEG transformation method, ${ }^{5)}$ which was developed for introducing plasmid DNA into B. brevis 47 , has several disadvantages when applied to $B$. brevis HPD31. This method showed a low efficiency as to the transformation of strain HPD31 with plasmid pBAM 101 ${ }^{6)}$ and no transformants were obtained with plasmids with a replication origin of $\mathrm{pHW1}^{7)}$ and $\mathrm{pWT} 481$. $^{8 \text { ) }}$

Electroporation, which was originaily developed for the genetic transformation of eukaryotic cells, was recently used to introduce DNAs into bacteria of: several species. $^{9 \sim 12)}$ We explored the possibility of efficient transformation of various strains of $B$. brevis with plasmid pBAM101 by electroporation. The transformation efficiency was determined by determining the number of neomycin-resistant and amylase positive colonies.

The standard transformation procedure for the electroporation of $B$. brevis HPD31 was as follows. An overnight culture in T2 medium ${ }^{1)}$ was diluted $(1: 100)$ with fresh broth and then grown at $37^{\circ} \mathrm{C}$ for $4 \mathrm{hr}$ to the early stationary phase of growth (optical density at $660 \mathrm{~nm}, 2.5$ ). Cells were harvested by centrifugation $(7,000 \times g, 5 \mathrm{~min}$, $4^{\circ} \mathrm{C}$ ), washed with an equal volume of cold electroporation buffer (SHC; 15\% glycerol, $272 \mathrm{~mm}$ sucrose, $16 \mathrm{~mm}$ HEPES (pH 7.0), I mM $\mathrm{CaCl}_{2}$ ) and then suspended in a $1 / 20$ volume of cold SHC. Aliquots of the suspension were frozen immediately at $-70^{\circ} \mathrm{C}$. This cell suspension could be stored without loss of transformation efficiency for at least 3 months. A Gene Pulser ${ }^{\mathrm{TM}}$ apparatus (Bio-Rad) was used to induce transformation. $0.8 \mathrm{ml}$ or $0.4 \mathrm{ml}$ of a cold competent cell suspension prepared as above was mixed with $10 \sim 50 \mu$ i of a plasmid DNA solution in a $0.4 \mathrm{~cm}$ electroporation cuvette (interelectrode distance, $0.4 \mathrm{~cm}$ ) or a $0.2 \mathrm{~cm}$ cuvette (interelectrode distance, $0.2 \mathrm{~cm}$ ). Electroporation was performed as follows: with the $0.4 \mathrm{~cm}$ cuvette, the Gene Pulser apparatus was set at $2.5 \mathrm{kV}$ and $25 \mu \mathrm{F}$, and the pulse controller was not used. With the $0.2 \mathrm{~cm}$ cuvette, it was set at $1.5 \mathrm{kV}$ and $25 \mu \mathrm{F}$, and the pulse controller was set at $1,000 \Omega$. After keeping on ice for a few minutes, the cell suspensions were mixed with $1 \mathrm{ml}(0.4 \mathrm{~cm}$ cuvette) or $0.5 \mathrm{ml}(0.2 \mathrm{~cm}$ cuvette) of MTB (T2 medium supplemented with $20 \mathrm{mM} \mathrm{MgCl}_{2}$ and $0.01 \%$ bovine serum albumin) and then held at $37^{\circ} \mathrm{C}$ for $1 \mathrm{hr}$. Cells were spread on selection agar plates and incubated at $37^{\circ} \mathrm{C}$.

At a constant capacitance of $25 \mu \mathrm{F}$, with the $0.4 \mathrm{~cm}$ cuvette, the transformation efficiency increased with the electric field strength, the highest efficiency being obtained at a field strength of $6.25 \mathrm{kV} / \mathrm{cm}$ (set at $2.5 \mathrm{kV}$ ), the upper limit of the apparatus. At a constant electric field strength of $6.25 \mathrm{kV} / \mathrm{cm}$, the highest efficiency was obtained at a capacitance of $25 \mu \mathrm{F}$, the upper limit of the apparatus. Under these conditions, the transformation efficiency was $1.3 \times 10^{4}$ transformants per $\mu \mathrm{g}$ of pBAM101. A higher electric field strength could be applied when the $0.2 \mathrm{~cm}$ electroporation cuvette was used. Under these conditions, the highest efficiency was obtained at $7.5 \mathrm{kV} / \mathrm{cm}$ (set at $1.5 \mathrm{kV}), 25 \mu \mathrm{F}$ and a resistance of $1,000 \Omega$ (time constant, $5 \mathrm{msec}$ ). The transformation efficiency was $2.6 \times 10^{4}$ transformants per $\mu \mathrm{g}$ of pBAM101.

Cells treated with lysozyme, proteinase, sodium dodecyl sulfate and alkaline buffer ( $50 \mathrm{~mm}$ Tris- $\mathrm{HCl}, \mathrm{pH} 8.5$ ) prior to electroporation were inferior to intact cells (data not shown). The transformation efficiency was greatly in-

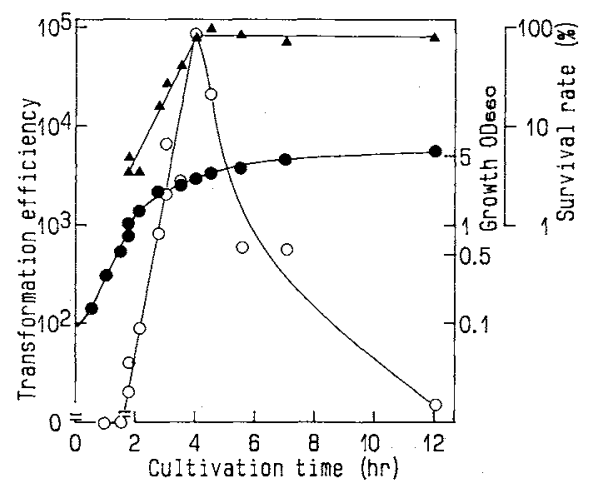

Fig. 1. Effect of the Growth Phase of B. brevis HPD31 on Transformation by Electroporation.

B. brevis HPD 31 was grown in $\mathrm{T} 2$ broth at $37^{\circ} \mathrm{C}$ with shaking and cells were harvested periodically. Electroporation was performed by the standard procedure. $\bigcirc$, transformation efficiency (transformants per $\mu \mathrm{g}$ pBAM101 DNA; O, growth (OD660); $\mathbf{A}$, survival rate $(\%)$ (ratio of viable cells before and after electroporation). 
Table I. Transformation EFficiencies of Various B. brevis Strains with Plasmid pBamiol ON ELECTROPORATION

\begin{tabular}{lcr}
\hline Strain & $\begin{array}{c}\text { Transformation } \\
\text { efficiency }\end{array}$ & $\begin{array}{c}\text { Survival } \\
\text { rate }(\%)^{a}\end{array}$ \\
\hline HPD31 & $1.3 \times 10^{4}$ & 35 \\
HPD52 & $1.0 \times 10^{1}$ & 32 \\
144 & $1.3 \times 10^{3}$ & 8 \\
HP1301 & $2.8 \times 10^{3}$ & 21 \\
444 & $4.0 \times 10^{1}$ & 4 \\
HP1502 & $2.0 \times 10^{1}$ & 5 \\
HP030 & 0 & 3 \\
HP1304 & 0 & 12 \\
HP1302 & 0 & 25 \\
HP032 & 0 & 2 \\
47 & 0 & 107 \\
481 & 0 & 40 \\
899 & 0 & 13 \\
HP601 & 0 & 2 \\
HP602 & 0 & 1 \\
HP603 & 0 & 2 \\
HP033 & 0 & 4 \\
HP037 & 0 & 8 \\
ATCC9999 & 0 & 1 \\
ATCC8185 & 0 & 2 \\
ATCC8246 & 0 & 3 \\
\hline
\end{tabular}

a See the legend to Fig. 1 .

fluenced by the growth phase at which the cells were harvested, as shown in Fig. 1. The efficiency was optimal with cells at the early stationary phase and almost no transformants appeared with cells at the early to mid exponential phase.

The transformation efficiencies of $B$. brevis HPD31 with other plasmids, pTS5 $(6.6 \mathrm{~kb}$ in size, carrying the human salivary amylase gene ${ }^{13)}$ and the replication origin of pHWl $)$ pHY $481^{8)}(3.7 \mathrm{~kb}$, carrying the replication origin of pWT481 isolated from $B$. brevis 481) and pHY $300 \mathrm{PLK}^{14)}(4.9 \mathrm{~kb}$, carrying the replication origin of pAM $\alpha 1$ ) were $4.2 \times 10^{3}, 1.4 \times 10^{3}$ and $3.2 \times 10^{3}$ transformants per $\mu \mathrm{g}$ DNA, respectively. Moreover, transformants were obtained with DNA in a ligation mixture by electroporation (data not shown).

Eighteen strains of protein-hyperproducing $B$. brevis, and 3 type and reference $B$. brevis strains were further examined as to the transformation efficiency on electroporation under the optimal conditions described above. As shown in Table 1, 6 strains were transformed, although the efficiency varied with the strain. All the transformants were found to carry the same plasmid as pBAM101. It is notable that no transformants were obtained from strain
47 by electroporation. Protein-producing B. brevis strains are classified morphologically into two groups. The cell wall of group I strains, such as HPD31 and HPD52, consists of a peptidoglycan layer and one protein layer, the so-called S-layer, whereas that of group II strains, such as 47 and HP033, consists of a peptidoglycan layer and two S-layers. ${ }^{15)}$ Cells having two S-layers may be resistant to electroporation. Therefore, the data obtained so far suggest a direct relationship between the cell wall structure and transformability through electroporation.

Though electroporation is not applicable to all $B$. brevis strains, it is a very useful method for transforming some strains of $B$. brevis.

\section{References}

1) H. Takagi, K. Kadowaki and S. Udaka, Agric. Biol. Chem., 53, 691 (1989).

2) H. Takagi, A. Miyauchi, K. Kadowaki and S. Udaka, Agric. Biol. Chem., 53, 2279 (1989).

3) M. Takao, T. Morioka, H. Yamagata, N. Tsukagoshi and S. Udaka, Appl. Microbiol. Biotechnol., 30, 75 (1989).

4) H. Yamagata, K. Nakahama, Y. Suzuki, A. Kakinuma, N. Tsukagoshi and S. Udaka, Proc. Natl. Acad. Sci. U.S.A., 86, 3589 (1989).

5) W. Takahashi, H. Yamagata, K. Yamaguchi, N. Tsukagoshi and S. Udaka, J. Bacteriol., 156, 1130 (1983).

6) N. Tsukagoshi, S. Iritani, T. Sasaki, T. Takemura, H. Ihara, Y. Idota, H. Yamagata and S. Udaka, J. Bacteriol., 164, 1182 (1985).

7) S. Horinouchi and B. Weisblum, J. Bacteriol, 150, 804 (1982).

8) H. Yamagata, K. Nakagawa, N. Tsukagoshi and S. Udaka, J. Bacteriol., 49, 1076 (1985).

9) B. M. Chassy and J. L. Flickinger, FEMS Microbiol. Lett., 44, 173 (1987).

10) J. G. Miller, W. J. Dower and L. S. Tompkins, Proc. Natl. Acad. Sci. U.S.A., 85, 856 (1988).

11) I. G. Powell, M. G. Achen, A. J. Hillier and B. E. Devidson, Appl. Environ. Microbiol., 54, 655 (1988).

12) S. Fiedler and R. Wirth, Anal. Biochem., 170, 38 (1988).

13) Y. Nakamura, M. Ogawa, T. Nishida, M. Emi, G. Kosaki, S. Himeno and K. Matsubara, Gene, 28, 263 (1984).

14) H. Ishiwa and H. Shibahara, Jpn. J. Genet., 60, 235 (1985).

15) K. Gruber, H. Tanahashi, A. Tsuboi, N. Tsukagoshi and S. Udaka, FEMS Microbiol. Lett., 56, 113 (1988). 